\title{
HCV among Male Injection Drug Users and their Female Partners in Almaty, Kazakhstan: Implications for HCV Treatment and Prevention
}

\author{
Nabila El-Bassel \\ Louisa Gilbert \\ Chris Beyrer \\ Assel Terlikbayeva \\ Elwin $\mathrm{Wu}$ \\ Follow this and additional works at: https://scholarsarchive.byu.edu/facpub \\ Part of the Medicine and Health Commons \\ See next page for additional authors
}

\section{Original Publication Citation}

El-Bassel, N., Gilbert, L., Beyrer, C., Terlikbayeva, A., Wu, E., Ma, X., Chang, M., Shaw, S.A., Zhussupov, B., Hunt, T., \& Rozental, Y. (2014). HCV among male injection drug users and their female partners in Almaty, Kazakhstan: Implications for HCV treatment and prevention. Journal of Therapy and Management in HIV Infection, 2(1), 1-9.

\section{BYU ScholarsArchive Citation}

El-Bassel, Nabila; Gilbert, Louisa; Beyrer, Chris; Terlikbayeva, Assel; Wu, Elwin; Ma, Xin; Chang, Mingway; Shaw, Stacey; Zhussupov, Baurzhan; Hunt, Tim; Primbetova, Sholpan; and Rozental, Yelena, "HCV among Male Injection Drug Users and their Female Partners in Almaty, Kazakhstan: Implications for HCV Treatment and Prevention" (2014). Faculty Publications. 2935.

https://scholarsarchive.byu.edu/facpub/2935

This Peer-Reviewed Article is brought to you for free and open access by BYU ScholarsArchive. It has been accepted for inclusion in Faculty Publications by an authorized administrator of BYU ScholarsArchive. For more information, please contact ellen_amatangelo@byu.edu. 


\section{Authors}

Nabila El-Bassel, Louisa Gilbert, Chris Beyrer, Assel Terlikbayeva, Elwin Wu, Xin Ma, Mingway Chang,

Stacey Shaw, Baurzhan Zhussupov, Tim Hunt, Sholpan Primbetova, and Yelena Rozental 


\title{
HCV among Male Injection Drug Users and their Female Partners in Almaty, Kazakhstan: Implications for HCV Treatment and Prevention
}

\author{
Nabila El-Bassel ${ }^{1, *}$, Louisa Gilbert ${ }^{1}$, Chris Beyrer ${ }^{2}$, Assel Terlikbayeva ${ }^{3}$, Elwin $\mathrm{Wu}^{1}$, \\ Xin Ma', Mingway Chang ${ }^{1}$, Stacey A. Shaw ${ }^{1}$, Baurzhan Zhussupov ${ }^{3}$, Tim Hunt ${ }^{1}$, \\ Sholpan Primbetova ${ }^{3}$ and Yelena Rozental ${ }^{3}$
}

${ }^{1}$ Global Health Research Center of Central Asia, Columbia University, New York City, 1255 Amsterdam Avenue, New York, NY 10027, USA

${ }^{2}$ Center for Public Health and Human Rights, Johns Hopkins Bloomberg School of Public Health, 615 N Wolfe St \#5041, Baltimore, MD 21205, USA

${ }^{3}$ Global Health Research Center of Central Asia, Columbia University, 102 Luganskogo St, Ap.1, Medeu District, Almaty 050059, Kazakhstan

\begin{abstract}
HCV infection is a serious concern among people who inject drugs. Despite imposing a major disease burden in countries with high rates of injection drug use such as Kazakhstan, other Central Asian and East Asian countries, Eastern Europe, and Russia, HCV remains an understudied issue. This study includes 728 individuals (364 couples) from Almaty, Kazakhstan, where at least one member of the dyad reported recent injection drug use. Participants were recruited to participate in a couple-based HIV prevention study. We examine the prevalence of HCV and co-infections between HCV and HIV, correlates of HCV, and the association between HCV prevalence and sexual behaviors after adjusting for non-injection illicit drug use, unsafe injection behaviors, and socio-demographic characteristics. Of the total sample, $90.2 \%$ of people who had ever injected drugs were diagnosed HCV positive and $15.5 \%$ of those who did not report injecting drugs were HCV positive. The prevalence of HIV and HCV co-infection among the total sample was $20.7 \%$. In the multivariate analysis, having sex while high on alcohol and/or drugs was associated with HCV after adjusting for unsafe injection practices, non-injection drug use, and socio-demographic characteristics (PR=1.20; 95\% $\mathrm{Cl}=1.04,1.39$ ). The high rates of HCV and co-infection of HIV and HCV found in the study underscore the need for attention to HCV testing and treatment among people who inject drugs in Kazakhstan and their sex partners.
\end{abstract}

Keywords: HCV, Injection drug use, Central Asia, HIV, Kazakhstan.

\section{INTRODUCTION}

A recent review estimating global, national, and regional prevalence rates of $\mathrm{HCV}$ among injection drug users (IDUs) in 77 countries found that HCV rates among IDUs ranged from $60-80 \%$ [1]. The review estimated that approximately 10 million IDUs (6.0-15.2 million) worldwide had been exposed to $\mathrm{HCV}$; thus, more IDUs are living with HCV than HIV(1). HCV imposes a major disease burden in countries that have high rates of IDU, such as Kazakhstan, other Central Asian and East Asian countries, Eastern Europe, and Russia [2-7]. UNAIDS estimates that $1 \%$ of Kazakhstani adults inject drugs [8]; however, this proportion exceeds $10 \%$ in towns along major drug trafficking routes across the country, representing one of the highest rates of injection drug use in the world [8].

*Address correspondence to this author at the Global Health Research Center of Central Asia, Columbia University, New York City, 1255 Amsterdam Ave, Room 814, New York, NY 10027, USA; Tel: (212) 851-2391; Fax: (212) 8512126; E-mail: ne5@columbia.edu, stacey.a.shaw@gmail.com
$\mathrm{HCV}$ is transmitted through unsafe injection practices [1,3] including sharing needles and other injection equipment such as cookers, rinse water, filters, or cotton [9]. Most people who become infected with HCV (75-85\%) develop chronic HCV infection, which can result in liver damage and liver failure over time [10]. Non-injection drug use has also been found to be associated with HCV infection. Drug users who do not inject can spread HCV by sharing straws/spoons to snort heroin or cocaine [2-4, 11-14] or by sharing crack smoking paraphernalia between people with oral lesions $[15,16]$, but studies on the link between HCV infection and non-injection drug use remain limited. Other factors found to be associated with HCV infection include older age [9, 17], a history of incarceration or detention, unsafe medical injections or transfusions [1], drug treatment [18], and duration of injection use, especially when longer than 10 years of use $[9,19]$.

HCV may also be spread through sexual contact, although transmission is less efficient than other sexually transmitted infections (STIs) [20-22]. Several case-controlled studies conducted mainly in the U.S. have identified well-documented instances of $\mathrm{HCV}$ 
infection after a defined sexual exposure [22-27]. Among patients with acute HCV infection in the U.S., $15-20 \%$ with no history of drug use reported a history of sexual contact with a person infected with HCV [22].

HCV infection has also been found to be associated with sexual risk behaviors among IDUs, including unprotected sex with someone who is HIV positive [3], anal sex, failure to use condoms, as well as having a higher number of sexual partners, a history of STIs, a sex partner with HCV infection [11, 28], and engaging in sex work [29]. In a study among heterosexual couples in an STI clinic in the U.S., females with HCV were 3.7 times more likely than those without HCV to have a HCV positive partner [30]. In spite of this growing evidence linking sexual risk behaviors and $\mathrm{HCV}$ infection, the mechanisms of sexual acquisition and transmission have not yet been identified.

To understand the spread of HCV, it is crucial to consider multiple structural factors that have been found to contribute to HIV risk among IDUs, including a lack of access to sterile needles, fear of harassment, discrimination, [31-34] poverty, arrest and incarceration [35-37], and barriers to HIV services and drug treatment [38-40]. These risk environments may also contribute to HCV among people who inject drugs.

As in other Central Asian countries, people who inject drugs face a number of governmental policies and structural barriers that prevent them from accessing harm reduction services and HCV and HIV care. While access to syringes and needles is legal and Kazakhstan currently has over 150 syringe/needle exchange programs, only $10-14 \%$ of IDUs utilize them [8]. The majority of people who inject drugs receive their syringes/needles from pharmacies. Methadone maintenance treatment was initiated in Kazakhstan in October 2008 as a pilot intervention for HIV positive IDUs within the national multicomponent HIV treatment project funded by the Global Fund to Fight AIDS, Tuberculosis, and Malaria (GFATM). Recently, three new pilot sites (Pavlodar, Temirtau, and UstKamenogorsk) were added, but political opposition has limited progress [41].

This paper describes the prevalence of $\mathrm{HCV}$ and co-infections of HCV and HIV among a sample of 728 individuals recruited to an HIV couple-based intervention.

We describe the prevalence of HCV by: (1) sociodemographic and economic characteristics (age, marital status, ethnicity, homelessness, food insecurity, and incarceration history); (2) injection drug use; (3) non-injection drug use; and (4) sexual risks. We describe associations between HCV and unsafe sexual practices (Having syphilis, engaging in unprotected sex, having more than one sex partner, using alcohol or drugs before sex), controlling for the effect of unsafe injection and socio-demographic characteristics, to explore if sexual risks (syphilis, unprotected sex, having multiple partners, using alcohol or drugs prior to sex) are associated with HCV. Although participants were recruited using a convenience sample, this descriptive study provides important data on a topic that has not been addressed in Kazakhstan and Central Asia.

\section{METHODS}

\section{Data Source}

This study uses baseline data from NIDA-funded Project Renaissance, conducted between 2009 and 2012 in Almaty, Kazakhstan. Project Renaissance was a randomized controlled trial to test the efficacy of a dyadic-focused HIV prevention intervention for couples where one or both partners report injecting drugs within 90 days. The Columbia University Institutional Review Board and the Kazakhstan School of Public Health Institutional Review Board approved the study.

\section{Recruitment Strategies}

Trained research assistants recruited potential study participants from known neighborhoods where IDUs gather as well as HIV clinics and needle exchange programs. Participants were also recruited via word-of-mouth from participants to their injection network members.

\section{Eligibility Criteria}

\section{Inclusion Criteria}

Couples were eligible to participate if they met the following criteria: (1) both were aged 18 or older; (2) both identified each other as their main partner of the opposite sex and someone whom the participant considered a boy/girlfriend, spouse, lover and/or parent of his/her child; (3) both reported the relationship had existed for at least 3 months; (4) both reported intending to remain together for at least 12 months; (5) at least one partner reported having had unprotected vaginal or anal intercourse with the other partner within the previous 90 days; and (6) at least one partner reported injecting drugs within the previous 90 days. 


\section{Exclusion Criteria}

Couples were excluded if they met any of the following criteria: (1) either partner showed evidence of psychiatric, physical, or neurological impairment that would limit effective participation in the study; (2) either partner reported severe physical or sexual violence perpetrated by the other partner in the past year, as determined on a Revised Conflict Tactics Scale [42]; (3) either partner reported that the couple was planning a pregnancy within the next 18 months; or (4) either partner was not fluent in Russian as determined during the informed consent process. Couples trying to get pregnant were excluded as the intervention was designed to increase condom use and couples trying to become pregnant may not be using condoms. A total of 971 individuals completed the screening interview. Of these, 728 met study eligibility criteria and completed the baseline interview. Of the 971 screened, 33 people were eligible but did not return to participate in the baseline.

\section{Data Collection}

Data collection included both self-reported data and objective biological assays. During the baseline visit, participants completed a 1.5-hour Audio Computer Assisted Self-Interview (ACASI) conducted in Russian in a private room. After the interview was completed, a Clinical Research Coordinator (CRC) conducted individual pre-test counseling related to HIV, HCV, and syphilis with each participant in a private room. Within two weeks of the baseline interview, the CRC notified each participant privately of his or her HIV, HCV, and syphilis test results, conducted post-test counseling, and provided referrals and navigation to treatment when applicable. Participants received the equivalent of $\$ 10$ USD for completing the baseline ACASI interview and biological testing.

\section{Measures}

\section{Socio-Demographic Variables}

Self-reported information was collected about participant socio-demographic characteristics including gender, age, ethnicity (Kazakh, Russian, or "other"), marital status (legally married and common-law marriage as "married," or divorced, separated, widowed, or never married as "unmarried"), and children (have children under 18 or not). Socioeconomic variables included years of education, homelessness (having no place to sleep within 90 days), and food insecurity (having insufficient money for food within 90 days). Measures of legal history included a history of incarceration.

\section{Current and Past Drug Use}

The Risk Behavior Assessment (RBA) [43, 44] was used to assess HCV risk behaviors and past drug use historically and within 90 days. Participants were considered to be injection drug users if they reported ever injecting drugs. Unsafe injection behaviors included using unclean syringes/needles; sharing cookers, cotton, rinse water, and other paraphernalia; splitting drug solutions with other injectors through front-loading, back-loading, or use of the same cooker/spoon, or adding their own or someone else's blood into an injected drug. If participants reported engaging in one or more of these behaviors within 90 days, their response was coded as $1=$ Yes for "any unsafe injection act within 90 days."

We also assessed the number of people a participant injected with within 90 days. We examined whether or not other drugs, including Demerol, morphine, Benadryl (diphenhydramine), speed, ephedrine, methadone, and Seduxen were mixed with heroin when a participant reported injecting heroin within 90 days. Participants reported whether they had used the following non-injection drugs within 90 days: heroin (smoked), marijuana (smoked), non-prescribed sedatives or barbiturates (Dimedrol, Seconal, Luminal, Librium, etc.), tranquilizers, sleeping pills or benzodiazepines (Valium, Relanium, Seduxen, etc.), methamphetamines (Fenamin, speed, Vint), or cocaine. Non-injection illicit drug use included whether the participant had used any non-injection drugs within 90 days. We assessed binge drinking by asking whether or not participants reported consuming 5 or more alcoholic drinks in a 6-hour period within 90 days.

\section{Sexual Behaviors}

Data were collected on sexual behaviors within 90 days including having unprotected vaginal sex with any partner, having vaginal sex with multiple partners, and having had vaginal or anal sex under the influence of alcohol or drugs with the main study partner.

\section{Biological Testing}

Biological assays were used to detect HIV, HCV, and syphilis. For HIV, HCV, and syphilis testing, a dried blood spot (DBS) technique was applied. A whole blood spot was obtained by a finger prick, applied to five printed circles on DBS filter paper cards, and sent to the reference laboratory at the Republican AIDS 
Center (RAC). For the serologic surveillance of HIV, $\mathrm{HCV}$, and syphilis, a standard enzyme-linked immunosorbent assay (ELISA test manufactured by Abbott Murex) was used [45]. Tests for all three biomarkers were conducted using a serial two-test strategy, as recommended by the World Health Organization and routinely used at the RAC. U.S. manufactured Abbott Murex Biotech tests were used for the second test. According to the RAC Guidelines for Serological Surveillance, the Murex anti HIV ABBOTT, Murex anti HCV ABBOTT, and the ICE Syphilis Murex ABBOTT each have a reported sensitivity of $>99.9 \%$ and specificity of $99 \%$.

\section{Statistical Analysis}

We used Chi-square tests or t-tests to test the bivariate relationships between HCV infection and each of the socio-demographic characteristics, injection drug use, non-injection drug use, and sexual risk behaviors. We examined whether sexual risks (syphilis antibody test positive, unprotected vaginal sex, having multiple sex partners, using alcohol or drugs before sex) were associated with HCV after adjusting for unsafe injection, non-injection drug use, and socio demographics (age, gender, marital status, years of education, and ethnicity).

To examine these associations, we performed a multivariate modified Poisson regression with random effects, which accommodated within-couple correlation due to non-independency of couple data.
The Poisson regression model was modified with a robust error variance ("Sandwich" or empirical covariance matrix) to yield a more reliable estimation of the confidence interval. The model also included covariance adjustment for socio-demographic characteristics. Prevalence ratios (PR) and their associated $95 \%$ confidence intervals $(\mathrm{Cl})$ are reported. All statistical analyses were performed in SAS 9.2.

\section{RESULTS}

\section{Socio-Demographic Characteristics}

Table 1 reports socio-demographic characteristics of 728 participants. The average age was 35.8 years $(\mathrm{SD}=7.8)$ and the majority of the sample was of Russian ethnicity (65.7\%). Nearly half (48.8\%) reported experiencing food insecurity within 90 days. Over twothirds of participants $(67.0 \%)$ had a history of incarceration. Participants had completed 11.4 years of education, on average.

HCV positive participants tended to be slightly older than those who were HCV negative (36.4 years vs. 33.7 years; $p<0.01)$. A greater number of HCV positive participants reported experiencing food insecurity within 90 days, compared to HCV negative participants $(51.1 \%$ vs. $41.8 \%$; $p<0.05)$. Incarceration rates were also higher among participants who were HCV positive when compared to those who were HCV negative $(80.4 \%$ vs. $26.9 \%$; $p<0.01)$.

Table 1: Socio-Demographic Characteristics by HCV Status $(\mathrm{N}=728 \text {, Female }=364 \text {, Male }=364)^{a}$

\begin{tabular}{|c|c|c|c|}
\hline & Total & $\mathrm{HCV}+$ & HCV- \\
\hline Age in years, mean (SD) & $35.8(7.8)$ & $36.4(7.3)^{\star *}$ & $33.7(8.9)$ \\
\hline \multicolumn{4}{|l|}{ Marital status, n (\%) } \\
\hline Married/common law marriage & $629(86.4)$ & $475(87.0)$ & $154(84.6)$ \\
\hline Unmarried & $99(13.6)$ & $71(13.0)$ & $28(15.4)$ \\
\hline Years of education, mean (SD) & $11.4(3.3)$ & $11.4(3.4)$ & $11.5(3.0)$ \\
\hline \multicolumn{4}{|l|}{ Ethnicity, n (\%) } \\
\hline Kazakh & $85(11.7)$ & $63(11.5)$ & $22(12.1)$ \\
\hline Russian & $478(65.7)$ & $365(66.9)$ & $113(62.1)$ \\
\hline Other & $165(22.7)$ & $118(21.6)$ & $47(25.8)$ \\
\hline Has children < 18, n (\%) & $385(52.9)$ & $281(51.5)$ & $104(57.1)$ \\
\hline Homeless within 90 days, n (\%) & $98(13.5)$ & $78(14.3)$ & $20(11.0)$ \\
\hline Insufficient money to buy food within 90 days, $\mathrm{n}(\%)$ & $355(48.8)$ & $279(51.1)^{*}$ & $76(41.8)$ \\
\hline Ever incarcerated, $\mathrm{n}(\%)$ & $488(67.0)$ & $439(80.4)^{\star *}$ & $49(26.9)$ \\
\hline
\end{tabular}

${ }^{*} p<0.05 ;{ }^{* *} p<0.01$.

Note: a. The significance tests for difference between HCV status were performed by chi-square or t-tests. 


\section{HCV Prevalence}

Table 2 shows that the prevalence of HCV for the total sample was $75.0 \%$. Male participants had a significantly higher $\mathrm{HCV}$ prevalence than females (88.2\% vs. $61.8 \%$; $p<0.01$ ), but men also had higher prevalence of ever injecting drugs (96.4\%) when compared to women (62.9\%). Among those who reported a history of injection drug use, HCV prevalence was not significantly different by gender. Some female participants who reported never injecting drugs had been infected with HCV (14.8\%). In $48.4 \%$ of $\mathrm{HCV}$ infections identified, the individual was not previously aware of being HCV positive.

More than half of the couples in the study (56.0\%) were HCV seroconcordant, over a third $(37.9 \%)$ were HCV serodiscordant, and in $6.0 \%$ of the couples, both partners were $\mathrm{HCV}$ negative. Among the total sample, the rate of HIV and HCV co-infection was $20.7 \%$. The co-infection rate was higher among IDUs than nonIDUs $(25.5 \%$ vs. $2.0 \%$; $p<0.01)$.

\section{HCV Prevalence and Drug Risks}

Table 3 describes HCV prevalence and injection drug risk behaviors among participants with a history of injection drug use $(n=580)$. The mean duration of injection history among IDUs was 15.6 years $(S D=7.8$ years), with HCV positive participants reporting a longer history of injection than $\mathrm{HCV}$ negative participants (16.1 years vs. 10.6 years; $p<0.01$ ). A number of injecting risk behaviors were associated with HCV positive status (see Table 3).

HCV positive participants were more likely than HCV negative participants to report use of non-injection drugs and binge drinking within 90 days.

\section{HCV Prevalence and Sexual Risk}

Table 3 describes the prevalence of HCV by sexual risk behaviors. One-fifth of those who had multiple sexual partners within 90 days were HCV positive while HCV negative participants were less likely to have multiple partners $(21.1 \%$ vs. $13.2 \% ; p<0.05)$. HCV positive participants were also more likely to report drinking alcohol or taking drugs before vaginal sex within 90 days than HCV negative participants $(85.4 \%$ vs. $57.1 \%$; $p<0.01$ ).

Table 4 reports the multivariate regression model examining HCV prevalence and sexual risk when adjusting for unsafe injection, non-injection drug use,

Table 2: HCV Characteristics ${ }^{a}$

\begin{tabular}{|c|c|c|c|}
\hline & Total $(\mathrm{N}=728)$ & Female $(n=364)$ & Male $(n=364)$ \\
\hline HCV positive, n (\%) & $546(75.0)$ & $225(61.8)$ & $321(88.2)^{\star *}$ \\
\hline HCV positive among IDUs $(n=580)$ & $523(90.2)$ & $205(89.5)$ & $318(90.6)$ \\
\hline HCV positive among non-IDUs $(n=148)$ & $23(15.5)$ & $20(14.8)$ & $3(23.1)$ \\
\hline $\begin{array}{l}\text { New detections of HCV, } n(\%) \text { (among total HCV positive, } \\
n=546 \text { ) }\end{array}$ & $264(48.4)$ & $117(52.0)$ & $147(45.8)$ \\
\hline HIV positive, n (\%) & $183(25.1)$ & $80(22.0)$ & $103(28.3)^{*}$ \\
\hline \multicolumn{4}{|l|}{ Co-occurring HIV/HCV } \\
\hline & Total $(\mathrm{N}=728)$ & IDUs $(\mathrm{N}=580)$ & Non-IDUs $(\mathrm{N}=148)$ \\
\hline Both HIV and HCV positive, $\mathrm{n}(\%)$ & $151(20.7)$ & $148(25.5)^{\star *}$ & $3(2.0)$ \\
\hline HIV positive and HCV negative, $\mathrm{n}(\%)$ & $32(4.4)$ & $19(3.3)$ & $13(8.8)^{\star \star}$ \\
\hline HIV negative and HCV positive, $\mathrm{n}(\%)$ & $395(54.3)$ & $375(64.7)^{* *}$ & $20(13.5)$ \\
\hline \multicolumn{4}{|l|}{ Couple-level status of HCV $(\mathrm{N}=364)$} \\
\hline Concordant positive, n (\%) & & \multicolumn{2}{|c|}{$204(56.0)$} \\
\hline Serodiscordant, n (\%) & & \multicolumn{2}{|c|}{$138(37.9)$} \\
\hline Male positive and female negative & & \multicolumn{2}{|c|}{$117(32.1)$} \\
\hline Male negative and female positive & & \multicolumn{2}{|c|}{$21(5.8)$} \\
\hline Concordant negative, $\mathrm{n}(\%)$ & & \multicolumn{2}{|c|}{$22(6.0)$} \\
\hline
\end{tabular}

${ }^{*} \mathrm{p}<0.05 ;{ }^{* *} \mathrm{p}<0.01$.

Note: a. The significance tests for gender and IDU status difference were performed by chi-square tests. 
Table 3: Sexual Risk, Injection and Non-Injection Drug Use by HCV Status $(\mathrm{N}=728)^{\mathrm{a}}$

\begin{tabular}{|c|c|c|c|}
\hline & Total & $\mathrm{HCV}_{+}$ & HCV- \\
\hline \multicolumn{4}{|l|}{ Sexual risk behaviors ( $n=728), n$ (\%) } \\
\hline $\begin{array}{l}\text { Had unprotected vaginal sex with any partner within } 90 \text { days, } \\
n(\%)\end{array}$ & $638(87.6)$ & $485(88.8)$ & $153(84.1)$ \\
\hline \multicolumn{4}{|l|}{ Injection drug use ( $n=580), n$ (\%) } \\
\hline Duration of drug injection history in years, ${ }^{b}$ mean (SD) & $15.6(7.8)$ & $16.1(7.7)^{\star *}$ & $10.6(6.6)$ \\
\hline Injected drugs within 90 days, ${ }^{\mathrm{b}} \mathrm{n}(\%)$ & $510(87.9)$ & $465(88.9)^{*}$ & $45(79.0)$ \\
\hline $\begin{array}{l}\text { Had access to needle exchange program within } 90 \text { days, } n \\
(\%)\end{array}$ & $38(5.2)$ & $35(6.4)^{\star}$ & $3(1.7)$ \\
\hline \multicolumn{4}{|l|}{ Non-injection drug and alcohol use ( $n=728), n(\%)$} \\
\hline Smoked heroin within 90 days & $49(6.7)$ & $34(6.2)$ & $15(8.2)$ \\
\hline Used cocaine within 90 days & $14(1.9)$ & $10(1.8)$ & $4(2.2)$ \\
\hline Used methamphetamines within 90 days & $13(1.8)$ & $10(1.8)$ & $3(1.7)$ \\
\hline Used marijuana within 90 days & $368(50.5)$ & $323(59.2)^{\star *}$ & $45(24.7)$ \\
\hline $\begin{array}{l}\text { Used non-prescribed sedatives, barbiturates, tranquilizers, } \\
\text { sleeping pills or painkillers within } 90 \text { days }\end{array}$ & $423(58.1)$ & $386(70.7)^{\star \star}$ & $37(20.3)$ \\
\hline
\end{tabular}

${ }^{*} \mathrm{p}<0.05 ;{ }^{* *} \mathrm{p}<0.01$.

Note: a. The significance tests for difference between HCV status were performed by chi-square tests. b. The analysis for drug-related risk behaviors only included those who had ever injected drugs ( $\mathrm{N}=580)$. Data are missing for 20 IDU cases (16 HCV positive, 4 HCV negative).

Table 4: Multivariate Modified Poisson Regression of HCV Status and Risk Behaviors with Random Effects ${ }^{a}$

\begin{tabular}{|c|c|c|c|}
\hline & PR & $95 \% \mathrm{Cl}$ & P-value \\
\hline Unsafe injections within 90 days & 1.38 & {$[1.25,1.53]$} & $<0.01^{* *}$ \\
\hline Syphilis antibody test positive & 1.09 & {$[0.97,1.21]$} & 0.139 \\
\hline Had unprotected vaginal sex with any partner within 90 days & 0.96 & {$[0.84,1.11]$} & 0.583 \\
\hline $\begin{array}{l}\text { Drank alcohol or took drugs before vaginal or anal sex with study } \\
\text { partner within } 90 \text { days }\end{array}$ & 1.20 & {$[1.04,1.39]$} & $0.014^{*}$ \\
\hline
\end{tabular}

${ }^{*} p<0.05 ;{ }^{* *} p<0.01$.

Note: a. The adjusted covariance are gender, age, marital status, years of education, and ethnicity.

and socio-demographic covariance. Using alcohol or drugs before sex with the study partner within 90 days was associated with $\mathrm{HCV}$ in the multivariate analysis (PR=1.20; 95\% $\mathrm{Cl}=1.04,1.39$ ). 


\section{DISCUSSION}

The $90 \%$ prevalence of HCV among IDUs supports earlier studies on the nexus between injection drug use and HCV $[1,17]$. A significant number of people who had injected drugs in this study were unaware that they were HCV positive - almost half of the HCV positive cases were newly detected.

A key finding from this study is that more than $14 \%$ of the female partners who reported no history of IDU were HCV positive. Some of these women may have injected drugs, but did not disclose use. These women may also have acquired HCV through risky sex with an HCV infected male partner, as one-third of the couples in the study were in HCV serodiscordant relationships in which the male partner was HCV positive.

Food insecurity may serve as a proxy for extreme poverty among study participants. Participants who did not have sufficient money to buy food had a higher prevalence of HCV than their counterparts. The rate of incarceration was higher among participants who were HCV positive compared to those who were negative. Being incarcerated may increase the risk of HCV. In prisons in Kazakhstan there is no access to clean needles and harm reduction services, which may increase risks for acquiring $\mathrm{HCV}$.

The finding that those who mixed heroin with diphenhydramine (Benadryl) had a higher prevalence of HCV than their counterparts could indicate that this mixture is a marker of addiction severity and higher frequency of injection. Benadryl may be used with lower quality heroin, to reduce side effects or allergic reactions, suggesting an association with drug users who are more economically vulnerable. Alternatively, mixing heroin with Benadryl can involve injecting the contents of capsules, which can cause obstructed veins, infections, or deep vein thrombosis [46], or using chopped pills which requires larger syringes and needles that may increase transmission likelihood.

Those who had ever attended a needle exchange program, compared to those who had not, also had a higher prevalence of HCV. Those who attended needle exchange programs may be more severely addicted, in worse physical condition, or older than IDUs who did not access needle exchange programs. People who use drugs in Kazakhstan are less likely to obtain needles from a needle exchange programs than from a pharmacist because of police harassment and limited hours of operation at needle exchange programs.
Excessive policing and fear of arrest can lead to sharing drug equipment, thus increasing risks of HCV, especially in public places where people who use drugs may rush injections. Individuals who cannot afford sufficient food may also be unable to purchase needles/syringes from pharmacists.

The prevalence of HCV among participants who reported using non-injection drugs such as marijuana, hashish, barbiturates, and/or binge drinking was higher than those who did not use these non-injection drugs or alcohol. The link between non injection drug use and HCV has been explained by previous research showing that drug use practices such as sharing pipes, spoons, or straws to sniff or snort drugs may increase HCV risk among non-IDUs $[3,5,11,13,14,19]$. However, the mechanisms that explain the relationship between use of non-injection drugs and HCV need further investigation. Non-injection drug use among IDUs may be a marker of severity or duration of addiction, which increases the propensity to engage in high-risk drug behaviors that may lead to acquiring $\operatorname{HCV}[3,9]$.

In the multivariate analysis examining the relationship between HCV and sexual risk, only using drugs or alcohol before having sex was associated with HCV infection. Those who use drugs and alcohol prior to sex may be less likely to use condoms during sex, which may increase risks for acquiring HCV. This link, however, needs further investigation. Research on sexual risk behavior and HCV remains limited, especially regarding the mechanisms that link the two among people who inject drugs.

Because this study was conducted with a nonrandom sample, findings may not be generalized to all people who inject drugs in Kazakhstan. Moreover, because of the cross-sectional nature of the study, the temporal relationships between risk behaviors and HCV infection cannot be determined. The descriptive findings reported in this paper provide insight on the scope of HCV prevalence and correlates with HCV among a sample that participated in an HIV prevention study. The study does not examine important environmental risk factors that may drive HCV such as fears of harassment and discrimination. Despite these limitations, the findings provide insight on the scope of HCV among people who use drugs in Kazakhstan. The findings also demonstrate major correlates with HCV, providing important $\mathrm{HCV}$ prevention, testing, and treatment implications that may also affect the HIV epidemic. 


\section{Implications for Treatment and Prevention}

The high prevalence of HCV observed in this study highlights the need for urgent attention to HCV testing and treatment among people who inject drugs in Kazakhstan. In many countries, including the U.S. and Great Britain, HCV treatment is recommended for all patient groups (including IDUs) and is considered cost effective [17]. Improving HCV treatment outcomes among IDUs and their sex partners should include education and training for couples, service providers, and primary care physicians on understanding HCV risks and recognizing the importance of receiving treatment. HCV prevention and treatment needs to be integrated into services for patients who are at risk for HIV as well as for those who are HIV positive. A longterm strategy for the control of HIV/HCV co-infection should encompass the prevention of both HIV and HCV [47] and co-infection treatment. Finally, reduction of stigma and discrimination related to both HCV and IDU are required in order to build a foundation for the uptake of HCV testing and treatment programs.

\section{ACKNOWLEDGEMENTS}

The study was funded to Dr. El-Bassel by the National Institute of Drug Abuse grant \# R01 DA022914-01A2.

\section{REFERENCES}

[1] Nelson PK, Mathers BM, Cowie B, et al. Global epidemiology of hepatitis $B$ and hepatitis $C$ in people who inject drugs: results of systematic reviews. Lancet 2011; 378: 571-83. http://dx.doi.org/10.1016/S0140-6736(11)61097-0

[2] Aceijas C, Rhodes T. Global estimates of prevalence of HCV infection among injecting drug users. Int J Drug Policy 2007; 18: 352-8. http://dx.doi.org/10.1016/j.drugpo.2007.04.004

[3] Hagan $\mathrm{H}$. Hepatitis $\mathrm{C}$ virus transmission dynamics in injection drug users. Subst Use Misuse 1998; 33: 1197-12. http://dx.doi.org/10.3109/10826089809062214

[4] Zhang T, Li Y, Lai JP, et al. Alcohol potentiates hepatitis C virus replicon expression. Hepatology 2003; 38: 57-65. http://dx.doi.org/10.1053/jhep.2003.50295

[5] Liu P, Xiang K, Tang $\mathrm{H}$, et al. Molecular epidemiology of human immunodeficiency virus type 1 and hepatitis $C$ virus in former blood donors in central China. AIDS Res Hum Retroviruses 2008; 24: 1-6.

http://dx.doi.org/10.1089/aid.2007.0144

[6] Aitken CK, Lewis J, Tracy SL, et al. High incidence of hepatitis $C$ virus reinfection in a cohort of injecting drug users. Hepatology 2008; 48: 1746-52. http://dx.doi.org/10.1002/hep.22534

[7] Walsh N, Maher L. HIV and viral hepatitis C coinfection in people who inject drugs implications of new direct acting antivirals for hepatitis $\mathrm{C}$ virus treatment. Curr Opin HIV AIDS 2012; 7: 339-44.

http://dx.doi.org/10.1097/COH.0b013e328354131e
[8]

[9]

[10]
UNAIDS. UNAIDS Report on the Global AIDS Epidemic. Switzerland: UNAIDS, 2010 Contract No.: Report.

Hagan H, Thiede H, Des Jarlais DC. HIV/hepatitis C virus coinfection in drug users: risk behavior and prevention. AIDS 2005; 19: S199-207.

CDC. Hepatitis C FAQs for the Public: Centers for Disease Control and Prevention; 2012 [cited 2013 Web Page]. Available from: http://www.cdc.gov/hepatitis/c/cfaq.htm

Gyarmathy VA, Neaigus A, Miller M, Friedman SR, Des Jarlais DC. Risk correlates of prevalent HIV, hepatitis B virus, and hepatitis $C$ virus infections among noninjecting heroin users. J Acquir Immune Defic Syndr 2002; 30: 448-56.

Howe CCJ, Fuller CM, Ompad DC, et al. Association of sex, hygiene and drug equipment sharing with hepatitis $C$ virus infection among non-injecting drug users in New York City. Drug Alcohol Depend 2005; 79: 389-95. http://dx.doi.org/10.1016/j.drugalcdep.2005.03.004

Tortu S, McMahon JM, Pouget ER, Hamid R. Sharing of noninjection drug-use implements as a risk factor for hepatitis C. Subst Use Misuse 2004; 39: 211-24. http://dx.doi.org/10.1081/JA-120028488

Roy K, Hay G, Andragetti R, Taylor A, Goldeberg D, Wiessing L. Monitoring hepatitis $\mathrm{C}$ virus infection among injecting drug users in the European Union: a review of the literature. Epidemiol Infect 2002; 129: 577-85. http://dx.doi.org/10.1017/S0950268802007902

Ti L, Buxton J, Wood E, Zhang R, Montaner J, Kerr T. Difficulty accessing crack pipes and crack pipe sharing among people who use drugs in Vancouver, Canada. Subst Abuse Treat Prev Policy 2011; 6: 34. http://dx.doi.org/10.1186/1747-597X-6-34

Ivsins A, Roth E, Nakamura N, Krajden M, Fischer B. Uptake, benefits of and barriers to safer crack use kit (SCUK) distribution programmes in Victoria, Canada-A qualitative exploration. Int J Drug Policy 2011; 22: 292-300. http://dx.doi.org/10.1016/j.drugpo.2011.05.005

Mehta SH, Genberg BL, Astemborski J, et al. Limited uptake of Hepatitis $C$ treatment among injection drug users. J Community Health 2008; 33: 126-33.

http://dx.doi.org/10.1007/s10900-007-9083-3

Beyrer C, Patel Z, Stachowiak JA, et al. Characterization of the Emerging HIV Type 1 and HCV Epidemics among Injecting Drug Users in Dushanbe, Tajikistan. AIDS Res Hum Retroviruses 2009; 25: 853-60.

\section{http://dx.doi.org/10.1089/aid.2008.0206}

Howe CJ, Fuller CM, Ompad DC, et al. Association of sex, hygiene and drug equipment sharing with hepatitis $C$ virus infection among non-injecting drug users in New York City. Drug Alcohol Depend 2005; 79: 389-95. http://dx.doi.org/10.1016/j.drugalcdep.2005.03.004

] Vandelli C, Renzo F, Romano L, et al. Lack of evidence of sexual transmission of Hepatitis $\mathrm{C}$ among monogamous couples: Results of a 10-year prospective follow-up study. Am J Gastroenterol 2004; 99: 855-9. http://dx.doi.org/10.1111/j.1572-0241.2004.04150.x

1] Terrault NA, Shiffman ML, Lok ASF, et al. A2ALL study group. Outcomes in hepatitis $C$ virus-infected recipients of living donor vs. deceased donor liver transplantation. Liver Transpl 2007; 13: 122-9. http://dx.doi.org/10.1002/lt.20995

Alter MJ. Epidemiology of hepatitis C virus infection. World J Gasteroenterol 2007; 13: 2436-41.

Desenclos JC. The challenge of hepatitis $C$ surveillance in Europe. Euro Surveill 2003; 8: 99-100.

Williams I. Epidemiology of hepatitis $C$ in the United States. Am J Med 1999; 107: 2S-9S.

http://dx.doi.org/10.1016/S0002-9343(99)00373-3 
[25] Hahn JA, Page-Shafer K, Lum PJ, Ochoa K, Moss AR. Hepatitis $C$ virus infection and needle exchange use among young injection drug users in San Francisco. Hepatology 2001; 34: 180-7.

http://dx.doi.org/10.1053/jhep.2001.25759

[26] Santantonio T, Medda E, Ferrari C, et al. Risk factors and outcome among a large patient cohort with community acquired acute Hepatitis C in Italy. Clin Infect Dis 2006; 43: 1154-9.

http://dx.doi.org/10.1086/507640

[27] Hofer H, Watkins-Riedel T, Janata O, Penner E, Holzmann $H$, Steindl-Munda $P$, et al. Spontaneous viral clearance in patients with acute hepatitis $\mathrm{C}$ can be predicted by repeated measurements of serum viral load. Hepatology 2003; 37(1): 60-4.

http://dx.doi.org/10.1053/jhep.2003.50019

[28] Kamal SM. Acute Hepatitis C: a systematic review. Am J Gastroenterol 2008; 103: 1283-97.

http://dx.doi.org/10.1111/j.1572-0241.2008.01825.x

[29] Butsashvili M, Tsertsvadze T, McNutt LA, Kamkamidze G, Gvetadze RJ, Badridze N. Prevalence of hepatitis B, hepatitis $\mathrm{C}$, syphilis and HIV in Georgian blood donors. Eur J Epidemiol 2001; 17: 693-5.

http://dx.doi.org/10.1023/A:1015566132757

[30] Thomas DL, Zenilman JM, Alter HJ, et al. Sexual transmission of hepatitis $\mathrm{C}$ virus among patients attending sexually transmitted diseases clinics in Baltimore--an analysis of 309 sex partnerships. J Infect Dis 1995; 171: 76875.

http://dx.doi.org/10.1093/infdis/171.4.768

[31] Chakrapani V, Newman P, Shunmugam M, Dubrow R. Social-structural contexts of needle and syringe sharing behaviours of HIV-positive injecting drug users in Manipur, India: a mixed methods investigation. Harm Reduct J 2011; 8: 9. http://dx.doi.org/10.1186/1477-7517-8-9

[32] Degenhardt L, Mathers B, Vickerman P, Rhodes T, Latkin C, Hickman M. Prevention of HIV infection for people who inject drugs: Why individual, structural, and combination approaches are needed. Lancet 2010; 376: 285-301. http://dx.doi.org/10.1016/S0140-6736(10)60742-8

[33] Strathdee SA, Lozada R, Martinez G, et al. Social and structural factors associated with HIV Infection among female sex workers who inject drugs in the Mexico-US border region. PloS One 2011; 6: e19048.

[34] Strathdee SA, Stockman JK. Epidemiology of HIV Among Injecting and Non-injecting Drug Users: Current Trends and Implications for Interventions. Curr HIV/AIDS Rep 2010; 7: 99-106. http://dx.doi.org/10.1007/s11904-010-0043-7

[35] Wechsberg WM, Luseno WK. The need for culturally appropriate, gender-specific global HIV prevention efforts with vulnerable women. J Prev Interv Community 2010; 38: 85-8.

http://dx.doi.org/10.1080/10852351003640559
[36] Auerbach JD, Parkhurst JO, Caceres CF. Addressing social drivers of HIV/AIDS for the long-term response: Conceptual and methodological considerations. Glob Public Health 2011; 6(Suppl 3): S293-309.

[37] Epperson MW, Khan MR, Miller DP, Perron BE, El-Bassel N, Gilbert L. Assessing criminal justice involvement as an indicator of human immunodeficiency virus risk among women in methadone treatment. J Subst Abuse Treat 2010; 38: $375-83$.

http://dx.doi.org/10.1016/j.jsat.2010.03.004

[38] Finkelstein R, Netherland J, Sylla L, Gourevitch MN, Cajina A, Cheever L. Policy implications of integrating buprenorphine/naloxone treatment and HIV care. J Acquir Immune Defic Syndr 2011; 56: S98-S104.

[39] Jablonowska E, Malolepsza E. Causes of antiretroviral therapy discontinuation in the outpatient HIV/AIDS clinic in Lodz. Przegl Epidemiol 2010; 64: 491-5.

[40] Tapp C, Milloy MJ, Kerr T, et al. Female gender predicts lower access and adherence to antiretroviral therapy in a setting of free healthcare. BMC Infect Dis 2011; 11: 86. http://dx.doi.org/10.1186/1471-2334-11-86

[41] Boltaev A, Deryabina A, Kusainov A, Howard A. Evaluation of a pilot medication-assisted therapy program in Kazakhstan: successes, challenges, and opportunities for scaleup. Adv Prev Med 2012; 2012: 308793. http://dx.doi.org/10.1155/2012/308793

[42] Straus MA. Measuring intrafamily conflict and violence: the conflict tactics (CT) scales. J Marriage Fam 1979; 41: 75-88. http://dx.doi.org/10.2307/351733

[43] Booth RE, Mikulich-Gilbertson SK, Brewster JT, Salomonsen-Sautel S, Semerik O. Predictors of self-reported HIV infection among drug injectors in Ukraine. J Acquir Immune Defic Syndr 2004; 35: 82-8.

http://dx.doi.org/10.1097/00126334-200401010-00012

[44] Needle R, Fisher DG, Weatherby N, et al. Reliability of selfreported HIV risk behaviors of drug users. Psychol Addict Behav 1995; 9: 242-50. http://dx.doi.org/10.1037/0893-164X.9.4.242

[45] Young $H$, Moyes A, Seagar L, McMillan A. Novel recombinant-antigen enzyme immunoassay for serological diagnosis of syphilis. J Clin Microbiol 1998; 36: 913-7.

[46] Higgs $P$, Dwyer R, Duong D, et al. Heroin-gel capsule cocktails and groin injecting practices among ethnic Vietnamese in Melbourne, Australia. Int J Drug Policy 2009; 20: $340-6$ http://dx.doi.org/10.1016/j.drugpo.2008.05.001

[47] Des Jarlais DC, Diaz T, Perlis $T$, et al. Variability in the incidence of human immunodeficiency virus, hepatitis B cirus, and hepatitis $C$ virus infection among young injecting drug users in New York City. Am J Epidemiol 2003; 157: 46771. http://dx.doi.org/10.1093/aje/kwf222

Received on 07-11-2013 Accepted on 26-12-2013 Published on 25-02-2014

DOI: http://dx.doi.org/10.12970/2309-0529.2014.02.01.1

(C) 2014 El-Bassel et al.; Licensee Synergy Publishers.

This is an open access article licensed under the terms of the Creative Commons Attribution Non-Commercial License (http://creativecommons.org/licenses/by-nc/3.0/) which permits unrestricted, non-commercial use, distribution and reproduction in any medium, provided the work is properly cited. 